Niniejsza publikacja jest dostępna na licencji Creative Commons. Uznanie autorstwa-Użycie niekomercyjne-Bez utworów zależnych 3.0 Polska. Pewne prawa zastrzeżone na rzecz autora. Zezwala się na wykorzystanie publikacji zgodnie z licencja - pod warunkiem zachowania niniejszej informacji licencyjnej oraz wskazania autora jako właściciela praw do tekstu. Treść licencji jest dostępna na stronie: http://creativecommons.org/licenses/by-nc-nd/3.0/pl/

Lingwistyka Stosowana 24: 4/ 2017, 165-176

\author{
Krzysztof WESOLOWSKI \\ Dorota AMBROŻUK \\ Uniwersytet Szczeciński
}

\title{
Interpretacja postanowień konwencji międzynarodowych zawierających normy o charakterze cywilnoprawnym
}

\begin{abstract}
Abstrakt:
Interpretation of the provisions of international conventions containing private law rules International conventions governing civil-law relationships are established as a result of compromise between various legal systems. Their terminology, as well and the institutions regulated by them are not always coherent with those deriving from the domestic legal systems. Therefore, it is necessary to apply different rules of interpretation to this type of regulations. The purpose of the paper is to answer the question to what extent the rules of interpretation, in particular language interpretation, developed in the jurisprudence, may be applied to civil law regulations included in the international conventions. The paper also aims at determining in what measure the rules of interpretation of international conventions arising from the Vienna Convention on the Law of Treaties may be useful for the same purpose.
\end{abstract}

\section{Wstęp}

Konwencje międzynarodowe zawierające normy o charakterze cywilnoprawnym, z natury swojej, znajdują zastosowanie w obrocie prywatnoprawnym pomiędzy równorzędnymi podmiotami. Służą one ujednoliceniu norm cywilnoprawnych w skali ponadnarodowej. Treść tych norm wypracowana została w drodze kompromisu pomiędzy przedstawicielami państw tworzących daną konwencję. Kompromis obejmuje nie tylko rozbieżne interesy, głównie gospodarcze, państw stron konwencji, ale również podmiotów stron stosunków cywilnoprawnych, regulowanych konwencją. Ponadto polega on na „godzeniu” różnych systemów i kultur prawnych, występujących w negocjujących państwach. Skutkiem tego jest celowe unikanie w konwencjach terminologii używanej w krajowych systemach prawnych i zastępowanie jej zwrotami neutralnymi, opisowymi ${ }^{1}$, a tym samym - niejasnymi (por. J. Jakubowski et al. 1983: 23), pozwalającymi na różną ich wykładnię, co może prowadzić do sprzeczności i niekompletności

\footnotetext{
${ }^{1} \mathrm{~Np}$. w art. 23 § 2 Konwencji o międzynarodowym przewozie kolejami (COTIF), sporządzonej w Bernie 9.05.1980 r. (Dz. U. z 1985 r. Nr 34, poz. 158), zmienionej Protokołem sporządzonym w Wilnie 3.06.1999 r. (Dz. U. z 2007 r. Nr 100, poz. 674), załączniku B (RU/CIM), dotyczącym przewozu towarów, czy też art. 17 ust. 2 Konwencji o umowie międzynarodowego przewozu drogowego towarów (CMR), sporządzonej w Genewie 19.05.1956 r. (Dz. U. 1962 r. Nr 49,
} 
(por. K.F. Haak 1987: 225). Stąd też, reguły stosowane przy interpretacji przepisów krajowych, w przypadku wykładni konwencji, mogą okazać się zawodne.

Celem artykułu jest wskazanie podmiotów dokonujących wykładni norm cywilnoprawnych zawartych w konwencjach międzynarodowych, jak i zasad, według których wykładnia ta powinna być dokonywana.

Z uwagi na wymogi wydawnicze dotyczące objętości tekstu, zagadnienia występujące w niniejszym opracowaniu niejednokrotnie zostały tylko wzmiankowane i wymagają dalszej, pogłębionej analizy.

\section{Podmioty dokonujące wykładni konwencji międzynarodowych}

Wykładni konwencji międzynarodowych mogą dokonywać państwa strony konwencji, na podstawie porozumień określanych mianem deklaracji interpretacyjnych. W przypadku konwencji zawierających normy cywilnoprawne, sytuacje takie zdarzają się jednak nader rzadko. Wykładnią takich konwencji zajmują się sądy lub sądy polubowne (sądy arbitrażowe) poszczególnych państw, stosując normy konwencyjne przy rozstrzyganiu sporów pomiędzy stronami stosunków, regulowanych przepisami danej konwencji. Znaczenie orzeczeń wydawanych przez te organy, a przede wszystkim ich moc wiążąca dla innych sądów czy organów administracji, zależy od rozwiązań przyjętych w danym państwie. Szczególną rolę odgrywają orzeczenia sądów wyższych instancji, zwłaszcza sądów najwyższych poszczególnych państw. Wprawdzie, interpretacja dokonywana przez te sądy nie ma charakteru wiążącego dla sądów (organów) innych państw, może jednak oddziaływać (i w praktyce oddziałuje) na ich orzecznictwo. Sądy bowiem coraz częściej, w wyrokach wydawanych z zastosowaniem przepisów konwencyjnych, odwołują się do orzeczeń sądów zagranicznych. Przykładem może być wyrok polskiego Sądu Najwyższego z 22.11.2007 r., w sprawie o sygn. III CSK 150/07, opublikowany w OSNC-ZD 2008, 53 z glosą K. Wesołowskiego, LEX/el. 2010, w uzasadnieniu którego Sąd Najwyższy odwołał się do opublikowanych stanowisk, wyrażonych w analogicznych sprawach, Sądu Najwyższego Austrii, Wyższego Sądu Krajowego w Monachium, jak i Sądu Apelacyjnego w Paryżu. Orzecznictwo obcych sądów, podobnie jak wypowiedzi literatury, stanowią tzw. pomocniczy środek interpretacji $\mathrm{w}$ rozumieniu art. 32 Konwencji wiedeńskiej o prawie traktatów z 23.05.1969 r., Dz. U. z 1990 r. Nr 74, poz. 439 (dalej KPT).

Niektóre konwencje ${ }^{2}$ przewidują możliwość rozstrzygania sporów pomiędzy umawiającymi się państwami-stronami tych konwencji przez Międzynarodowy Trybunał Sprawiedliwości (MTS). Rozwiązanie to nie ma jednak większego znaczenia w praktyce (na teoretyczny charakter przyjętego rozwiązania zwraca uwagę I. Bon-Garcin 2006: 712). Spory powstałe na tle stosowania konwencji zawierających głównie normy cywilnoprawne, nie przybierają bowiem - co do zasady - charakteru sporów prawno-

poz. 238 ze zm.), użyto opisowego zwrotu „okoliczności, których przewoźnik nie mógł uniknąć i których skutkom/następstwom nie mógł zapobiec” zamiast terminu ,siła wyższa”.

${ }^{2}$ Tak np. konwencja CMR (patrz przypis 1), której art. 47 stanowi, że każdy spór między dwiema lub wieloma państwami-stronami konwencji, dotyczący interpretacji lub jej stosowania, którego strony nie mogłyby uregulować drodze rokowań lub w inny sposób, może być wniesiony na żądanie którejkolwiek z zainteresowanych stron do MTS. 
międzynarodowych, w których stronami są państwa, a tylko państwa, zgodnie z art. 34 ust. 1 statutu MTS, mają prawo stawać jako strony przed MTS. W przypadku takiego sporu pomiędzy państwami, wyrok wydany przez MTS wiązałby tylko państwa występujące $\mathrm{w}$ sporze $\mathrm{w}$ charakterze stron lub ewentualnie interwenientów, co znajduje potwierdzenie w art. 59 statutu MTS $^{3}$. Zasadniczo brak jest zatem organu wymuszającego jednolitą wykładnię konwencji w skali ponadnarodowej.

W odniesieniu do państw Unii Europejskiej, pewną rolę w tym zakresie odgrywa natomiast Trybunał Sprawiedliwości Unii Europejskiej (dalej TSUE lub Trybunał). Trybunał ten w oparciu o przepis art. 267 Traktatu o funkcjonowaniu Unii Europejskiej (Dz. Urz. UE C 2012/326, dalej TFUE), władny jest orzekać w trybie prejudycjalnym o wykładni traktatów oraz aktów przyjętych przez instytucje, organy i jednostki organizacyjne Unii Europejskiej. Nie wszystkie konwencje, będące przedmiotem niniejszego artykułu, można zaliczyć do prawa unijnego. Nie ulega wątpliwości, że aktami takimi są umowy międzynarodowe (konwencje), do których Unia Europejska przystąpiła $^{4}$. Stanowią one źródła prawa międzynarodowego, ale są jednocześnie zaliczane do źródeł prawa unijnego i stąd mieszczą się w dyspozycji ww. art. 267 TFUE. Trybunał uznał swoją kompetencję także do dokonywania wykładni tzw. umów mieszanych (umów zawartych zarówno przez państwa członkowskie, jak i UE, gdyż dotyczą dziedzin z zakresu kompetencji podzielonych), a nawet umów, których stroną UE nie jest. Chodzi o przypadki tzw. następstwa funkcjonalnego (przejęcia przez UE obowiązków państw członkowskich, wynikających z zawartych przez te państwa umów międzynarodowych), szczególnego nadania kompetencji TFUE w treści konwencji, odesłania do konwencji międzynarodowych zawartego w prawie unijnym lub przyjęcia przepisów prawa unijnego $\mathrm{w}$ celu realizacji postanowień umów międzynarodowych (bliżej K. Wesołowski 2013: 74).

Za niepokojące uznać jednak należy, pojawiające się od pewnego czasu, zjawisko wychodzenia przez TSUE poza swoje kompetencje i dokonywania $\mathrm{w}$ istocie wykładni postanowień konwencji szczególnych, nie należących do prawa unijnego (nawet tak szeroko pojętego). Praktykę taką można zaobserwować w przypadku spraw, w których następuje zbieg norm wynikających z konwencji szczególnej i norm prawa unijnego. Trybunał dokonuje wówczas wykładni konwencji niejako „tylnymi drzwiami”, tzn. formalnie interpretuje przepisy prawa unijnego (do czego jest uprawniony), ale poprzez pryzmat norm unijnych formułuje warunki stosowania przepisów konwencji szczególnej. Tym samym dokonuje wykładni konwencji, naruszając zasadę autonomii prawa międzynarodowego (zob. K. Wesołowski 2011: 287 i 290).

\footnotetext{
${ }^{3}$ Zgodnie z art. 59 statutu MTS, wyrok sądu wiąże tylko strony występujące w sporze i tylko w stosunku do danego sporu.

${ }^{4}$ Zgodnie z art. 216 TFUE, Unia Europejska posiada zdolność traktatową, może zatem zawierać umowy międzynarodowe, które wiążą instytucje UE, jak i państwa członkowskie. Przykładami takich umów są: wspomniana w przypisie 1 konwencja COTIF, a także Konwencja w sprawie ujednolicenia niektórych zasad dotyczących międzynarodowego przewozu lotniczego $\mathrm{z}$ 28.05.1999 r. (Dz. U. z 2007 r. Nr 37, poz. 235), określana mianem konwencji montrealskiej.
} 
Przykładem mogą być wyroki Trybunału z 4.05.2010 r. w sprawie C-533/08, TNT Express Nederland (ECLI:EU:C:2010:243 ${ }^{5}$ ) oraz z 19.12.2013 r. w sprawie C-452/12, Nipponkoa Insurance Co. (Europe) (ECLI:EU:C:2013:858). W obu wyrokach Trybunał odniósł się do relacji art. 71 rozporządzenia Rady (WE) nr 44/2001 z 22.12.2000 r. w sprawie jurysdykcji i uznawania orzeczeń sądowych oraz ich wykonywania w sprawach cywilnych i handlowych ${ }^{6}$ do postanowień art. 31 konwencji CMR, tj. konwencji, co do której Trybunał nie posiada kompetencji do dokonywania jej wykładni (co sam zresztą w tych wyrokach wprost przyznał). Przepis art. 71 rozporządzenia nr 44/2001 stanowi ${ }^{7}$, że rozporządzenie to nie narusza konwencji, których państwa członkowskie są stronami i które w sprawach szczególnych regulują jurysdykcję, uznawanie lub wykonywanie orzeczeń. Najogólniej rzecz ujmując, z treści postanowienia art. 71 rozporządzenia nr 44/2001 wynika, że w przypadku zbiegu w danej sprawie norm konwencji szczególnych i norm ww. rozporządzenia, zastosowanie znajdują przepisy konwencji. $\mathrm{W}$ wyroku z 4.05.2010 r. Trybunał stwierdził jednak, że art. 71 rozporządzenia $\mathrm{nr}$ 44/2001 należy interpretować w ten sposób, że postanowienia konwencji szczególnej, odnoszące się do zasady zawisłości sporu (art. 31 ust. 2 konwencji CMR), jak i zasady wykonywalności orzeczeń sądowych (art. 31 ust. 3 tej konwencji) będą miały zastosowanie, ale pod warunkiem, że są w wysokim stopniu przewidywalne, ułatwiają prawidłowy wymiar sprawiedliwości i umożliwiają, tak dalece jak to tylko jest możliwe, uniknięcia ryzyka równoległych postępowań oraz zapewniają, na warunkach co najmniej równie korzystnych, jak te przewidziane w rozporządzeniu $\mathrm{nr} 44 / 2001$, swobodny przepływ orzeczeń w sprawach cywilnych i handlowych oraz wzajemne zaufanie do wymiaru sprawiedliwości w ramach UE (favor executionis). Jeszcze dalej idące stwierdzenia zawarte zostały w wyroku z 19.12.2013 r., w którym Trybunał stwierdził, że art. 71 rozporządzenia nr 44/2001 należy interpretować w ten sposób, że stoi on na przeszkodzie wykładni konwencji międzynarodowej w sposób, który nie zapewnia na warunkach co najmniej równie korzystnych, jak te przewidziane przez to rozporządzenie, poszanowania celów i zasad leżących u podstaw wspomnianego rozporządzenia. Ponadto Trybunał stwierdził, że art. 71 rozporządzenia nr 44/2001 należy interpretować w ten sposób, że stoi on na przeszkodzie wykładni art. 31 ust. 2 konwencji CMR, zgodnie z którą, powództwo o ustalenie nieistnienia stosunku prawnego lub prawa, lub wyrok ustalający nieistnienie stosunku prawnego lub prawa, w jednym państwie członkowskim nie dotyczy tego samego roszczenia, co powództwo regresowe wytoczone z tytułu tej samej szkody między tymi samymi stronami lub ich następcami prawnymi,

\footnotetext{
${ }^{5}$ Rzecznik Generalny w ww. sprawie - J. Kokkot, w swojej opinii stwierdza jednak wprost o dokonaniu wykładni konwencji CMR przez Trybunał (J. Kokkot 2010).

${ }^{6}$ Dz. Urz. WE L 12 z 16.01.2001: 1, polskie wydanie specjalne Dz. Urz. UE 2004, rozdz. 19, t. 4: 42.

7 Rozporządzenie $\mathrm{nr}$ 44/2001 obecnie już nie obowiązuje, gdyż zastąpione zostało rozporządzeniem Parlamentu Europejskiego i Rady (UE) nr 1215/2015 z 12.12.2012 r. w sprawie jurysdykcji i uznawania orzeczeń sądowych oraz ich wykonywania w sprawach cywilnych i handlowych (Dz. Urz. UE. L. 2012.351.1). Jednakże brzmienie art. 71 rozporządzenia $\mathrm{nr} 44 / 2001$ nie uległo zasadniczej zmianie w stosunku do brzmienia art. 71 rozporządzenia nr 1215/2012. Stąd problem relacji art. 71 rozporządzenia nr 1215/2012 do przepisów konwencji szczególnych pozostaje wciąż aktualny.
} 
w innym państwie członkowskim (szerzej na temat konsekwencji prawnych ww. wyroku zob. D. Ambrożuk 2015: 197-209). Co ciekawe, we wcześniejszych wyrokach Trybunał opowiadał się w sposób jednoznaczny za prymatem stosowania postanowień konwencji szczególnych ${ }^{8}$ i jedynie posiłkowym stosowaniem przepisów ogólnych, w odniesieniu do tych przypadków, których przepisy konwencji szczególnych nie regulują.

\section{Języki autentyczne jako podstawa wykladni}

Podstawą wykładni konwencji międzynarodowych powinny być ich oryginalne wersje, sporządzane z reguły w kilku językach, z których każdy ma jednakową moc, chyba że sama konwencja stanowi lub jej strony uzgodniły, że w przypadku rozbieżności określony tekst jest rozstrzygający ${ }^{9}$ (tak art. 33 ust. $1 \mathrm{KPT}$ ).

Powyższa regulacja powoduje, że interpretacja konwencji jest znacznie trudniejsza w porównaniu do norm prawa krajowego, szczególnie gdy dana konwencja została sporządzona w kilku językach autentycznych i nie wskazano, który tekst jest rozstrzygający. Ma to miejsce np. w odniesieniu do konwencji CMR, sporządzonej w języku angielskim i francuskim, konwencji montrealskiej, sporządzonej w języku angielskim, arabskim, chińskim, francuskim, hiszpańskim i rosyjskim czy Konwencji Narodów Zjednoczonych o umowach międzynarodowej sprzedaży towarów z 11.04.1980 r. (Dz. U. z 1997 r. Nr 45, poz. 286, dalej konwencja wiedeńska), sporządzonej również w ww. sześciu językach. Wówczas - zgodnie z zasadą równoważności tekstów autentycznych - proces wykładni powinien obejmować analizę wszystkich wersji językowych (por. A. Wyrozumska 2006: 361, M. Czepelak 2008: 417-419).

$\mathrm{Z}$ przeprowadzenia powyższej analizy nie zwalnia domniemanie zawarte $\mathrm{w}$ art. 33 ust. 3 KPT, a mianowicie, że wyrazy użyte w traktacie (konwencji międzynarodowej) mają to samo znaczenie w każdym z tekstów autentycznych. Może ono być jedynie pomocne w ustaleniu znaczenia wyrazów użytych w wersjach autentycznych konwencji (por. M. Czepelak 2008: 418). Jeżeli bowiem w jednym z tekstów autentycznych wyraz jest rozumiany jednoznacznie, a w innym ma różne znaczenie, ale jedno $\mathrm{z}$ tych znaczeń jest takie samo, jak w pierwszej wersji językowej, to - zgodnie z powyższym domniemaniem - przyjąć należy takie jego znaczenie, chyba że co innego wynika z

8 Chodzi np. o wyrok z 28.10.2004 r. w sprawie C-148/03, Nürnberger Allgemeine Versicherung (ECLI:EU:C:2004:677) czy wyrok z 6.12.1994 r. w sprawie C-406/92, Tatry v. Maciej Rataj (ECLI:EU:C:1994:400).

${ }^{9}$ Tak np. Konwencja o ujednostajnieniu niektórych prawideł dotyczących międzynarodowego przewozu lotniczego z 12.10.1929 r. (Dz. U. z 1933 r. Nr 8, poz. 49), sporządzona w j. francuskim, zmieniona protokołem haskim z 28.09.1955 r. (Dz. U. z 1963 r. Nr 33, poz. 189) sporządzonym w j. francuskim, angielskim i hiszpańskim, gdzie rozstrzygającym jest j. francuski, dalej konwencja warszawska, Konwencja o ujednostajnieniu niektórych prawideł dotyczących międzynarodowego przewozu lotniczego wykonywanego przez inną osobę niż przewoźnik umowny z 18.09.1961 r. (Dz. U. z 1965 r. Nr 25, poz. 167), dalej konwencja z Gadajalaja, sporządzona w j. francuskim, angielskim i hiszpańskim, gdzie rozstrzygający jest j. francuski czy też konwencja COTIF, sporządzona w j. angielskim, niemieckim i francuskim, gdzie również językiem rozstrzygającym jest j. francuski. 
innych metod interpretacji, np. wykładni funkcjonalnej. Kryterium rozstrzygającym jest zatem to, który z tekstów w wyższym stopniu realizuje założenia teleologiczne interpretowanego postanowienia (tak K. Wesołowski 2013: 91, por. też wyrok Naczelnego Sądu Administracyjnego z 3.12.2009 r., II FSK 917/08, Legalis dostęp 06.05.2017, w którym sąd ten wskazał, że odmiennie niż w porządku aktu prawa krajowego, dyrektywy wykładni umów międzynarodowych nakazują w procesie wykładni uwzględnić zawsze nie tylko wykładnię językową, ale nawet w sytuacji językowej jasności postanowień umowy, sięgnąć po wykładnię teleologiczną).

W przypadku konwencji sporządzonych w kilku językach autentycznych, w tym np. chińskim czy arabskim, dyrektywa nakazująca uwzględnianie wszystkich wersji językowych w praktyce może być niezwykle trudna do spełnienia. Wydaje się, że w takiej sytuacji, jako wymóg minimalny, postulować należałoby dokonanie wykładni w oparciu o języki konwencji najbliższe stronom stosunku prawnego, regulowanego przepisami tej konwencji. W żadnym jednak przypadku kwestie wątpliwe nie mogą być rozstrzygane na podstawie jednej wersji językowej.

W odniesieniu do tych konwencji, których postanowienia mają, co do zasady, charakter dyspozytywny, za dopuszczalne uznać należy umowne dokonanie wyboru przez strony sporu jednej z autentycznych wersji językowych konwencji, w oparciu o którą będą rozstrzygane ewentualne spory powstałe pomiędzy nimi. W przypadku konwencji zawierających przepisy bezwzględnie wiążące, dokonanie takiego wyboru stanowiłoby naruszenie zasady równoważności języków autentycznych (por. M. Pazdan 2001: 128 oraz K. Wesołowski 2013: 92).

W świetle powyższego, niedopuszczalne jest dokonywanie interpretacji konwencji jedynie $\mathrm{w}$ oparciu o tekst będący jej tłumaczeniem $\mathrm{z}$ języka lub języków autentycznych, nawet, gdy tekst taki stanowi oficjalny przekład, zamieszczony w organie promulgacyjnym. Reguła ta nie zawsze jest jednak przestrzegana. Przykładem dokonania takiej wykładni jest wyrok Sądu Najwyższego z 22.11.2007 r., III CSK 150/07 (OSNC-ZD 2008: 53), z uzasadnienia, którego wynika, że SN dokonywał analizy językowej jedynie polskiego przekładu konwencji CMR. Usprawiedliwieniem powyższej praktyki nie może być przepis art. 6 ustawy z 7.10.1999 r. o języku polskim ${ }^{10}$, w świetle którego ,umowy międzynarodowe zawierane przez Rzeczpospolitą Polską powinny mieć polską wersję językową, stanowiącą podstawę wykładni, chyba że przepisy szczególne stanowią inaczej”. W orzecznictwie podkreśla się, że przepisy traktatów międzynarodowych, dotyczące ustanowienia tekstu o walorze rozstrzygalności, w razie rozbieżności językowej różnych tekstów autentycznych tego samego traktatu, są właśnie owymi przepisami szczególnymi, o których mowa $\mathrm{w}$ art. 6 ustawy o języku polskim. Co więcej, ponieważ traktaty międzynarodowe zwierają normy rangi wyższej niż normy ustawowe, to zastosowanie znajduje tu także reguła kolizyjna lex superior derogat legi inferiori. Pogląd ten pozostaje $\mathrm{w}$ zgodzie z normami konstytucyjnymi, gdyż zasada, że język polski jest urzędowym językiem Rzeczypospolitej Polskiej (art. 27 Konstytucji RP) musi być ograniczona na rzecz realizacji, wyrażonej w art. 9 Konstytucji RP, zasady, iż

${ }^{10}$ T.j. Dz. U. z 2011 r. Nr 43, poz. 224 ze zm. 
Rzeczypospolita Polska przestrzega wiążącego ją prawa międzynarodowego (tak NSA w powołanym wyżej wyroku z 22.11.2007 r.).

Również w doktrynie wskazuje się, że art. 6 ustawy o języku polskim ma zastosowanie jedynie wówczas, gdy umowa międzynarodowa sformułowana została także w języku polskim jako jednym z języków autentycznych, a jednocześnie brak jest w niej postanowienia, dotyczącego pierwszeństwa wersji językowych (tak. K. Górny 2009: 25). Trzeba też przyjąć, że postanowienia przepisów KPT mają pierwszeństwo w świetle postanowień art. 91 ust. 2 w zw. z art. 241 ust. 1 oraz art. 89 ust. 1 pkt 5 i ust. 3 Konstytucji RP.

\section{Opinia biegłego co do rozumienia pojęć i zwrotów użytych w autentycznych wersjach językowych}

Przedstawiony wyżej wymóg stosowania autentycznych wersji językowych konwencji, a także możliwość występowania rozbieżności pomiędzy tymi wersjami, powoduje, że sąd orzekający w sprawach podlegających danej konwencji może stanąć przed trudnym dla niego problemem ustalenia właściwej treści konwencji, będącej podstawą rekonstrukcji normy prawnej, która w sprawie powinna być zastosowana. Trudno zakładać, że każdy sędzia posiada stosowna wiedzę i umiejętności językowe, aby uporać się z problemem, o którym mowa. Pojawia się zatem kwestia możliwości skorzystania z opinii biegłych. Musi być ona oceniana na podstawie właściwych przepisów proceduralnych, obowiązujących w państwie sądu.

W Polsce ewentualne zastosowanie mogłoby mieć postanowienie art. $278 \S 1$ k.p.c. ${ }^{11}$, umożliwiające powołanie biegłych w wypadkach wymagających wiadomości specjalnych. Kwestia może być jednak problematyczna. Wprawdzie przepis nie rozstrzyga czy wiadomości, o których mowa, mają dotyczyć wyłącznie faktów, czy też innych okoliczności, niemniej jednak zasadniczo przyjmuje się, że przedmiotem dowodu z opinii biegłego nie może być treść prawa (zobacz jednak pogląd wyrażony w pracy J. Jodłowskiego et al. 2002: 387), którzy wśród przedmiotu opinii biegłego wymieniają m.in. przepisy regulujące transport). Wyjątek stanowi prawo obce i obca praktyka sądowa (art. $1143 \$ 3$ k.p.c. ${ }^{12}$ ). Tymczasem ratyfikowana i ogłoszona w Dzienniku Ustaw konwencja międzynarodowa, będąca elementem krajowego

\footnotetext{
${ }^{11}$ Przepis art. 278 ustawy z 17.11.1964 r. - Kodeks postępowania cywilnego (t.j. Dz. U. z 2016 r. poz. 1822 ze zm., dalej k.p.c.) stanowi, że w wypadkach wymagających wiadomości specjalnych, sąd po wysłuchaniu wniosków stron co do liczby biegłych i ich wyboru może wezwać jednego lub kilku biegłych w celu zasięgnięcia ich opinii.

${ }^{12}$ Zgodnie z przepisem art. $1143 \$ 3$ k.p.c, celem ustalenia treści prawa obcego lub obcej praktyki sądowej albo istnienia wzajemności sąd może zastosować także inne środki (chodzi o środki inne niż wymienione w §1 i 2 art. 1143, czyli zwrócenie się do Ministra Sprawiedliwości o udzielenie tekstu prawa obcego, wyjaśnienie obcej praktyki sądowej, jak również o udzielenie informacji co do istnienia wzajemności w stosunkach z państwem obcym), w tym zasięgnąć opinii biegłych.
} 
porządku prawnego (art. 91 ust. 1 Konstytucji $\mathrm{RP}^{13}$ ), nie może być uznana za prawo obce.

Wydaje się, że kwestia może być jednak pozytywnie rozwiązana, poprzez właściwe ustalenie przedmiotu opinii biegłego. Nie może być nim całościowa wykładnia określonego przepisu ani też dokonywanie subsumcji, tj. stwierdzanie, że stan faktyczny, będący przedmiotem postępowania, mieści się w zakresie normy na jego podstawie zrekonstruowanej. Czynności te należą do sądu. Rola biegłego powinna się sprowadzać do zdefiniowania znaczenia określonych pojęć i wyrażeń w autentycznym języku czy językach konwencji, a zatem do kwestii czysto lingwistycznych. Ustalenie treści normy prawnej, wynikającej z interpretowanych przepisów, poprzez zastosowanie także innych pozajęzykowych metod i dyrektyw wykładni należy do sądu orzekającego w sprawie (tak M. Czepelak 2008: 432).

\section{Stosowanie prawa traktatów do wykładni konwencji o charakterze cywilnoprawnym}

Wykładania konwencji międzynarodowych zawierających normy o charakterze cywilnoprawnym, powinna być dokonywana z uwzględnieniem postanowień art. 31-33 KPT, mających swe źródło w normach prawa zwyczajowego. Wprawdzie zostały one zredagowane przede wszystkim na potrzeby konwencji międzynarodowych, regulujących typowe stosunki prawno-międzynarodowe, tj. pomiędzy państwami i innymi podmiotami prawa międzynarodowego publicznego, brak jest jednak przesłanek pozwalających na ich pominięcie przy wykładni konwencji międzynarodowych, zawierających normy prawa cywilnego (por. M. Czepelak 2008: 386, A. Wyrozumska 2006: 333, 355-358, C. Bernasconi 1999: 139, A.V.M. Struycken 1999: 135, J.H.A. van Loon 1987: 224, A. von Overbeck 1971: 40).

W myśl art. 31 ust. $1 \mathrm{KPT}$, wyrażającego tzw. ogólną regułę interpretacyjną, ,traktat należy interpretować w dobrej wierze, zgodnie ze zwykłym znaczeniem, jakie należy przypisywać użytym w nim wyrazom w ich kontekście, oraz w świetle jego przedmiotu i celu". Interpretacja konwencji w dobrej wierze polega na takiej na jej wykładni, która nie kwestionuje potrzeby użytych w niej pojęć, czyni umowę międzynarodową możliwą do wykonania i nie wyprowadza z niej obciążeń, które nie są konieczne dla prawidłowego jej wykonania (tzw. zasada proporcjonalności), (por. L. Ehrlich 1957: 7-8). Jednocześnie, zgodnie z zasadą wykładni tekstualnej (obiektywnej) należy przyjąć, że jej strony miały taką intencję, jaka wynika ze zwyczajnego znaczenia użytych w niej wyrażeń (por. A. Wyrozumska 2006: 335, C. Bernasconi 1999: 140). Podmiot dokonujący wykładni nie powinien odwoływać się zatem do subiektywnej intencji stron (ich intencji i motywów, które nie zostały uzewnętrznione w tekście konwencji). Postulat ten jest szczególnie aktualny w przypadku konwencji wielostronnych, zawie-

\footnotetext{
${ }^{13}$ Zgodnie z art. 91 ust. 1 Konstytucji RP z 2.04.1997 (Dz. U. Nr 78, poz. 483), ratyfikowana umowa międzynarodowa, po jej ogłoszeniu w Dzienniku Ustaw Rzeczypospolitej Polskiej, stanowi część krajowego porządku prawnego i jest bezpośrednio stosowana, chyba że jej stosowanie jest uzależnione od wydania ustawy.
} 
rających normy o charakterze generalno-abstrakcyjnym. Odmienne podejście sprzeciwiałoby się zasadzie pewności obrotu (por. S. E. Nahlik 1976: 199). Specjalne znaczenie należy przypisywać wyrazom tylko wówczas, gdy ustalono, że taki był zamiar stron (art. 31 ust. 4 KPT).

Dokonując wykładni konwencji, oprócz interpretacji tekstualnej, należy równolegle uwzględnić kontekst, w jakim dane wyrażenie zostało użyte oraz przedmiot i cel konwencji, gdyż w świetle art. 31 ust. 1 KPT żadna z ww. metod wykładni, tj. obiektywna, kontekstualna (systemowa), jak i celowościowa, nie ma pierwszeństwa. Kontekst konwencji, zgodnie z art. 31 ust. 2 KPT, obejmuje nie tylko jej tekst wraz ze wstępem i załącznikami, ale również każde porozumienie jej dotyczące, osiągnięte między wszystkimi stronami, a także każdy dokument sporządzony przez jedną lub więcej stron w związku z zawarciem konwencji, przyjęty przez inne strony, jako dokument odnoszący się do tej konwencji (tzw. wąski charakter kontekstu - por. A. Kozłowski 2002: 79). Dokonując wykładni systemowej konwencji, oprócz ww. kontekstu (czyli uwzględnienia tekstu konwencji i ww. dokumentów), należy łącznie z nim wziąć pod uwagę: 1) każde późniejsze porozumienie między stronami, dotyczące interpretacji konwencji i stosowania jej postanowień, 2) każdą późniejszą praktykę stosowania konwencji, ustanawiającą porozumienie stron co do jej interpretacji, 3) jak i wszelkie odpowiednie normy prawa międzynarodowego, mające zastosowanie w stosunkach między stronami (art. 31 ust. 3 KPT). Niezależnie od tego, przy wykładni konwencji, brać należy pod uwagę jej zmiany lub uzupełnienia, dokonane stosownymi protokołami, nawet wówczas, gdy orzeka sąd państwa, które protokołu tego nie ratyfikowało. W tym ostatnim przypadku nie chodzi o stosowanie przepisów tych protokołów, a o ich uwzględnienie przy wykładni samej konwencji. Przykładowo, istnienie i treść protokołu do konwencji CMR z 2008 r. w sprawie elektronicznego listu przewozowego, powinny być brane pod uwagę przez polskie sądy, pomimo nieratyfikowania tego protokołu przez Polskę, przy wykładni postanowień samej konwencji, wprowadzających wymóg pisemnej formy listu przewozowego czy innych oświadczeń, w kontekście elektronicznych form przekazywania danych.

Powyższe zasady, pomijające całkowicie normy prawa krajowego, przesądzają o konieczności dokonywania tzw. autonomicznej wykładni konwencji międzynarodowej, zgodnie z którą, dokonując interpretacji użytych w niej pojęć i wyrażeń, należy abstrahować od znaczenia, w jakim występują one w prawie krajowym, chyba że co innego wynika $\mathrm{z}$ treści samej konwencji. Jak podkreśla się w nauce prawa, konwencja międzynarodowa stanowi bowiem samodzielny system prawa (tak M. Czepelak 2008: 397, 441-443, por. też K. Wesołowski 2013: 82). Niedopuszczalne jest wobec tego dokonywanie analogii z przepisów prawa wewnętrznego czy też z innych konwencji międzynarodowych, choćby regulowały podobną problematykę (np. umowę przewozu $\mathrm{w}$ innej gałęzi transportu). Dopuszczalna jest natomiast wykładnia porównawcza. W ramach tej wykładni, dopuszczalne jest też porównywanie praktyki stosowania danej konwencji w poszczególnych państwach. Chodzi o zapewnienie w maksymalnym stopniu celów konwencji (por. K.F. Haak 1987: 225), w tym także poprzez interpretację dynamiczną, zapewniającą objęcie jej regulacją także stanów faktycznych nie branych pod rozwagę przez jej twórców (M.A. Clarke 2002: 215-216). 
Jak już wyżej wskazano, postanowienie art. 31 ust. 1 KPT nakazuje, aby dokonując wykładni wyrażeń użytych w konwencji brać pod uwagę także przedmiot i jej cel. W konwencjach międzynarodowych są one najczęściej określane $\mathrm{w}$ ich preambułach (wstępach). Uwzględnienie przedmiotu i celu sprowadza się do takiej interpretacji konwencji, aby poszczególne jej postanowienia nie były pozbawione sensu (znaczenia), a także aby miały użyteczne znaczenie, zgodnie z zasadą efektywności (por. A. Wyrozumska 2006: 345). Przy ustalaniu celu konwencji szczególnie pomocna może się okazać dokumentacja z okresu jej tworzenia oraz wypowiedzi jej twórców, stanowiące tzw. uzupełniające środki interpretacji.

O uzupełniających środkach interpretacji traktatów (konwencji) stanowi art. 32 KPT. Do środków tych można się odwołać, w celu potwierdzenia znaczenia wynikającego z zastosowania przepisów art. $31 \mathrm{KPT}$ (tzw. ogólnej reguły interpretacyjnej) lub gdy wykładnia oparta na powołanych wyżej przepisach art. 31 KPT pozostawia znaczenie użyte w traktacie dwuznacznym lub niejasnym, albo prowadzi do rezultatu wyraźnie absurdalnego lub nierozsąannego. Przez uzupełniające środki interpretacji należy rozumieć przede wszystkim wymienione wprost $\mathrm{w}$ art. $32 \mathrm{KPT}$ prace przygotowawcze (travaux préparatoires) do traktatu i okoliczności jego zawarcia, jak również orzecznictwo sądów zagranicznych i poglądy nauki prawa (por. M. Czepelak 2008: 413, K.F. Haak 1987: 229, M.A. Clarke 2009: 10-11). W odniesieniu do prac przygotowawczych zalecana jest jednak duża ostrożność, zwłaszcza wówczas, gdy od uchwalenia danej konwencji upłynęło dużo czasu.

\section{Podsumowanie}

Jak wynika z powyższych uwag, interpretacja konwencji międzynarodowych zawierających normy cywilnoprawne jest procesem bardziej złożonym w porównaniu do wykładni prawa wewnętrznego. Przedmiotem wykładni są teksty autentyczne konwencji. W przypadku równoważnych tekstów (co jest regułą) konieczne jest uwzględnienie znaczenia wynikającego ze wszystkich tych tekstów. W odniesieniu do konwencji sporządzonych w wielu autentycznych językach, postulat ten może być trudno wykonalny. Stąd też, jako minimum, należy przyjąć analizę konwencji w językach najbliższych stronom stosunku cywilnoprawnego, regulowanego przepisami danej konwencji. W przypadku konwencji zawierających normy dyspozytywne, dopuszczalny jest wybór przez strony stosunku prawnego regulowanego treścią konwencji wiążącej wersji językowej.

Interpretacja konwencji międzynarodowych, zawierających normy cywilnoprawne, odbywa się zasadniczo przy użyciu tych samych metod, co interpretacja prawa krajowego (metoda językowa zwana też tekstualną, systemowa zwana również kontekstualną, celowościowa zwana także teologiczną, porównawcza). Stosowanie tych metod musi jednak uwzględniać zasady wykładni traktatów, unormowane przepisami KPT. Choć zostały one opracowane na potrzeby konwencji międzynarodowych, regulujących typowe stosunki prawno-międzynarodowe, powinny być także stosowane przez sądy $i$ inne organy, dokonujące wykładni konwencji międzynarodowych, zawierających normy prawa cywilnego. Z zasad tych wynika konieczność równoległego i równoważnego stosowania wszystkich ww. metod wykładni. Wykładnia tekstualna 
powinna być oparta na normalnym znaczeniu użytych pojęć i zwrotów. Subiektywny zamiar twórców konwencji, nie znajdujący odzwierciedlenia w obiektywnie odczytywanych postanowieniach, nie może być brany pod uwagę, zwłaszcza, że stronami takich konwencji są często państwa nie biorące udziału w procesie ich tworzenia. Postulat tzw. wykładni autonomicznej nakazuje, aby przy interpretacji użytych w konwencji zwrotów o prawnym charakterze, $\mathrm{z}$ dużą ostrożnością odwoływać się do przypisanych im znaczeń na gruncie prawa krajowego. W różnych systemach prawa ich znaczenie może być różne. Dążyć zatem należy do nadania im takiego sensu, który w najwyższym stopniu realizował będzie cele konwencji jako takiej i jej poszczególnych przepisów (wykładnia celowościowa). Jednocześnie istnieje konieczność uwzględnienia tzw. kontekstu (wykładnia systemowa, kontekstualna). W jej ramach nie można abstrahować od protokołów zawierających zmiany i uzupełnienia do konwencji, nieratyfikowane przez państwo sądu dokonującego wykładni. Ich istnienie i treść rzutują bowiem na sposób rozumienia pierwotnego tekstu konwencji.

\section{Bibliografia}

Ambrożuk, D. (2015), Zagadnienie tożsamości roszczeń w sprawach transportowych (Uwagi na tle wyroku TSUE z 19 grudnia 2013), (w:) ,Zeszyty Naukowe Uniwersytetu Szczecińskiego” 871, „Problemy Transportu i Logistyki” 30, 198-209.

Bernasconi, C. (1999), Rules of Interpretation Applicable to Private International Law Treaties: an Overview, (w:) W.P. Heere (red.), International Law and The Hague's 750th Anniversary. The Hague, 139-149.

Bon-Garcin, I. (2006), The 50th Anniversary of the CMR Convention - Future and Perspectives of International Road Transport, Conclusions of the Symposium held at Deauville (France) - 18-19.May 2006, (w:) „Uniform Law Review” 3, 698-714.

Clarke, M.A. (2002), Carriage by Road. A Multimodal Mix-up, (w:) „Journal of Business Law" 2, 210-217.

Clarke, M.A. (2009), International Carriage of Goods by Road: CMR (Maritime and Transport Law Library). London.

Czepelak, A. (2008), Umowa międzynarodowa jako źródto prawa prywatnego międzynarodowego. Warszawa.

Ehrlich, L. (1957), Interpretacja traktatów. Warszawa.

Górny, K. (2009), Problemy błędnego thumaczenia art. 3 Konwencji Organizacji Narodów Zjednoczonych o umowach międzynarodowej sprzedaży towarów (CISG), (w:) „Przegląd Ustawodawstwa Gospodarczego" 2, 25-30.

Haak, K.F. (1987), The CMR - Interpretation, (w:) J. Theunis (red.) International Carriage of Goods by Road (CMR). London etc., 224-234.

Jakubowski, J./ M. Tomaszewski/ A. Tynel/ A.W. Wiśniewski (1983), Zarys międzynarodowego prawa handlowego. Warszawa.

Jodłowski, J./ Z. Resich/ J. Lapierre/ T. Misiuk-Jodłowska (2002), Postepowanie cywilne. Warszawa.

Kokott, J. (2010), Opinia Rzecznika Generalnego z 28.01.2010 w sprawie C 533/08. ECLI:EU:C:2010:50. 
Kozłowski, A. (2002), Interpretacja traktatu międzynarodowego $w$ świetle jego kontekstu. Warszawa.

Loon, J.H.A. van (1987), The Hague Conventions on Private International Law, (w:) F.G. Roberts (red.), The Effect of Treaties in Domestic Law (Uknccl Series 7). London, 221-251.

Nahlik, S.E. (1976), Kodeks prawa traktatów (Polski Instytut Spraw Miedzynarodowych). Warszawa.

Overbeck, A. von (1971), L'application par le juge interne des conventions de droit international privé, ( $\mathrm{w}$ :) ,Recueil des cours de l'Académie de droit international de la Haye" t. I, vol. 132, 1-106.

Struycken, A.V.M. (1999), Interpretation of Private Law Treaties: Introductory Remarks, (w:) W.P. Heere (red.), International Law and The Hague's 750th Anniversary. The Hague, 135-139.

Wesołowski, K. (2011), Relacje między CMR a prawem unijnym w orzecznictwie Trybunału Sprawiedliwości Unii Europejskiej, (w:) „Zeszyty Naukowe Uniwersytetu Szczecińskiego 644. Problemy Transportu i Logistyki“" 14, 279-295.

Wesołowski, K. (2013), Umowa międzynarodowego przewozu drogowego towarów na podstawie CMR. Warszawa.

Wyrozumska, A. (2006), Umowy międzynarodowe, teoria i praktyka. Warszawa. 